\title{
Assembly Lines and Contra Dance Lines: The Ford Motor Company Music Department and Leisure Reform
}

\author{
KATHERINE BRUCHER
}

\begin{abstract}
The automaker Henry Ford founded the Ford Motor Company Music Department in 1924 with the goal of reviving what he called "old-fashioned dancing and early American music." Ford's interest in the Anglo-American social dances of his youth quickly grew from dances hosted by the Fords for company executives to a nationwide dance education program. This article traces the history of the Music Department's dance education program and examines the parallels between it and the company's earlier efforts in social engineering-namely the Ford Profit Sharing Plan (better known as the "Five Dollar Day") and the Ford English School. The Music Department's activities offer an opportunity to explore how industry sought to shape music and dance through Americanization efforts and leisure reform as Detroit rapidly urbanized during the first decades of the twentieth century. Supporters of Ford's revival viewed the restrained musical accompaniment and dance movements as an antidote to jazz music and dances, but more importantly, music and dance served as an object lesson in the physical discipline necessary for assembly line labor. Ford's dance education campaign reveals the degree to which industry was once entwined with leisure reform in southeast Michigan.
\end{abstract}

There have been imported into the United States of recent years dances that originated on the African Kongo, dances from the gypsies of South American pampas and dances from the hot-blooded races of Southern Europe ... [Henry] Ford is firmly convinced that dancing of a rational and racially American character is capable of being developed into an invaluable instrument for social righteousness.

-William C. Richards, quoted in "Return of the Dance," Dearborn Independent, 6 Jun $1925 .{ }^{1}$

In 1925, "Return of the Dance" boldly announced the automaker Henry Ford's goals for a revival of what he called "old-fashioned dancing" and "early American music." This editorial, reprinted a few months later as "Henry Ford Shakes a Wicked Hoof" in Literary Digest, was one of many items published in national magazines and newspapers that profiled Ford's growing interest in Anglo-American social dances of the nineteenth century. The anonymous writer's use of racialized

I extend gratitude to the many people who read and commented on this essay over the years. I would especially like to thank Gillian Rodger for her guidance during the earliest stages of the project and the staff at the Benson Ford Research Center, Dearborn Historical Museum, and the Bentley Historical Library for all of their help. Thanks also to Victoria Clark, whose astute comments as JSAM assistant editor set the direction for this article.

${ }^{1}$ Reprinted as "Henry Ford Shakes a Wicked Hoof," Literary Digest, 15 August 1925, 40. Richards quotes "a Ford dance book" that is "being prepared." This statement likely refers to the first edition of "Good Morning": After a Sleep of Twenty-Five Years Old-Fashioned Dancing is Being Revived by Mr. and Mrs. Henry Ford (Dearborn, MI: Dearborn Publishing Company, 1925).

${ }^{2}$ Ford used adjectives "old-fashioned" and "early American" to indicate dance and music based on his idea of nineteenth-century repertory, which is distinct from contemporary old-time music. Throughout the essay, I use old-fashioned dance and early American music to indicate Ford's terminology. 
language suggests how the early twentieth century politics of class, immigration, and race underscored perceptions of dance. Ford spearheaded a nationwide dance education campaign that promoted the dances he recalled from his youth under the auspices of the Music Department of the Ford Motor Company, but his efforts to develop dance as "an instrument for social righteousness" were more than just an exercise in nostalgia. Ford founded the Music Department in 1924. Its activities were official company business, and its employees were on the company payroll. For the next twenty-three years, until Ford's death in 1947, Music Department employees accompanied dances, gave lessons throughout Michigan, and promoted social dancing nationwide through publications, radio broadcasts, recordings, teaching, and touring. I argue that Ford's revival of "old-fashioned dance" can be best understood as part of his broader efforts at Americanization through leisure reform. The campaign reconfigured Victorian era Anglo-American values for an American population that included more immigrants and was more centered on industry in urban areas than ever before.

Industrial paternalism provided the impetus for the Ford Music Department. This familial metaphor denotes an employer's provision of "something beyond wages" and employee deference to an employer. ${ }^{3}$ Cloaked in the language of nostalgia and revival, an education in old-fashioned dancing furthered Henry Ford's goal of efficient factory labor and a docile workforce. His desire to shape a culture compatible with the demands of the factory manifested itself in efforts to shape children's leisure activities. Reformers such as Ford considered children an essential part of the process of assimilating immigrants and their descendants into model workers. ${ }^{4}$ Dancing offered not only an opportunity for supervised physical exercise, viewed as important for children living in cramped urban conditions, but it also could be used to teach manners and sociability consistent with reformers' worldviews. Social dances such as contra dancing, with its emphasis on group interaction, interlocking patterns of movement, and precise timing that propels dancers down the line, served as an object lesson in the virtues of modern factory work. Dancing provided a way to teach students Ford's notion of American values and social deportment as well as physical discipline suited to the modern factory workplace. What came to be known as Fordism extended beyond the factory floor and permeated life outside the factory through the bodies of dancing children. ${ }^{5}$ Viewed alongside the Ford Motor Company's earlier efforts in social engineering, namely the Ford Profit Sharing Plan (better known as the "Five Dollar Day") and the Ford English School, ${ }^{6}$ Ford's revival of "old-fashioned dance" illustrates how

\footnotetext{
${ }^{3}$ Andrea Tone, The Business of Benevolence: Industrial Paternalism in Progressive America (Ithaca, NY: Cornell University Press, 1997), 1.

${ }^{4}$ Ibid., 93.

${ }^{5}$ See Greg Grandin, Fordlandia (New York: Metropolitan Books, Henry Holt, 2009), 73 for a short history of the term "Fordism."

${ }^{6}$ For further accounts of Henry Ford's efforts at social reform, see Neil Baldwin, Henry Ford and the Jews (New York: Public Affairs, 2001); Grandin, Fordlandia; Stephen Meyer, III, "Adapting the Immigrant to the Line: Americanization in the Ford Factory, 1914-1921," Journal of Social History 14, no. 1 (Autumn 1980): 67-82; Stephen Meyer, III, The Five Dollar Day (Albany: State University of New York Press, 1981).
} 
the body functioned as a focal point for class, gender, and race anxieties in the cultural politics of leisure reform in early twentieth-century Detroit.

Henry Ford's influence as a public figure should not be underestimated when considering his advocacy of social dancing. Ford was a hero to many Americans; he embodied the myth of the self-made man-rising from Michigan farm boy to founder of one the world's largest companies. By the mid 1920s, Ford routinely received public approval ratings higher than the president of the United States, and his widespread public appeal guaranteed that the national press recorded even his most mundane comments. ${ }^{7}$ His opinions on issues as diverse as farming practices, public health, and United States history regularly attracted the attention of the media. Ford's interest in social dancing received extensive press coverage, and he used print media and radio to reach a national audience. ${ }^{8}$

Scholars who have documented Ford's music and dance program have reached dramatically different conclusions regarding his motivations. Faye Witt Moreland and Eva Twork both provide useful book-length overviews of the automaker's music and dance activities. These authors attribute Ford's sponsorship of music and dance to his industrial and social beneficence. ${ }^{9}$ In contrast, Emery C. Warnock views the music and dance campaign as an outgrowth of Ford's earlier anti-Semitic campaigns, and Peter La Chapelle argues that Ford's efforts to promote Anglo-American music and dance reflects the influence of Nordicist theories that the decline of a northern European master race would lead to the downfall of civilization. ${ }^{10} \mathrm{I}$ draw on Paul Gifford's essay, "Henry Ford's Dance Revival and Fiddle Contests: Myth and Reality," published in this journal, for its extensive documentation of the founding of the Ford Music Department. Gifford attributes the revival to Ford's nostalgia. ${ }^{11}$ He traces a craze for fiddling contests to the music and dance campaign, but he also shows that although Ford hired many local fiddlers to perform for him, the fiddling contests were mainly promotional events hosted by Ford dealerships. ${ }^{12}$ The question of how Ford's old-fashioned dance and early American music campaign

\footnotetext{
${ }^{7}$ David Lewis, The Public Image of Henry Ford (Detroit, MI: Wayne State University Press, 1976), 213.

${ }^{8}$ Ibid., 226; Paul Gifford, "Henry Ford's Dance Revival and Fiddle Contests: Myth and Reality," Journal of the Society for American Music 4, no. 3 (2010): 324-26; Peter La Chapelle, "'Dances Partake of the Racial Characteristics of the People Who Dance Them': Nordicism, Antisemitism, and Henry Ford's Old-Time Music and Dance Revival," in The Song Is Not the Same: Jews in American Life, ed. Bruce Zuckerman, Josh Kun, and Lisa Ansell, The Jewish Role in American Life 8 (2011): 35-38, 54.

${ }^{9}$ Faye Witt Moreland, Green Fields and Fairer Lanes: Music in the Life of Henry Ford (Tupelo, MS.: Five Star, 1969); Eva O'Neal Twork, Henry Ford and Benjamin B. Lovett: The Dancing Billionaire and the Dancing Master (Detroit, MI: Harlo, 1982).

${ }^{10}$ Emery C. Warnock, "The Anti-Semitic Origins of Henry Ford's Arts Education Patronage," Journal of Historical Research in Music Education 30, no. 2 (April 2009): 79-102; La Chapelle, "'Dances Partake of the Racial Characteristics of the People Who Dance Them,"” 42.

${ }^{11}$ Gifford, "Henry Ford's Dance Revival," 327-32.

${ }^{12}$ Additional accounts of Ford's efforts to promote fiddling and square dance include Paul Gifford, “Jasper E. 'Jep' Bisbee: Old-Time Michigan Dance Fiddler," The Old Time Herald 9, no. 6 (Winter 2004-2005), http://www.oldtimeherald.org/archive/back_issues/volume-9/9-6/ jasper-bisbee.html; Chris Goertzen, "The Transformation of American Contest Fiddling," Journal of Musicology 6, no. 1 (Winter 1988): 107-29; Colin Quigley, "Reflections on the Hearing to 'Designate the Square Dance as the American Folk Dance of the United States': Cultural Politics and an American Vernacular Dance Form," Yearbook for Traditional Music 33 (2001): 45-57.
} 
parallels his broader interests in leisure and social reform has remained relatively unexplored. My essay continues Gifford's work on Ford's revival but with a renewed focus on how leisure reform, with its attendant politics of race and class, shaped the Ford Music Department. The campaign, in turn, influenced subsequent efforts by Ford and others to use nineteenth-century social dances as a twentieth-century pedagogical tool. Moreover, Henry Ford's activities draw attention to the musical history of southeast Michigan. Most accounts of music, dance, Americanization, and leisure reform have focused on Chicago and New York as urban centers with heavy industry and large immigrant populations, but Michigan's auto industry, too, attracted thousands of workers and their families from overseas and throughout the country. ${ }^{13}$ Ford's music and dance revival offers an opportunity to explore how Americanization efforts developed as Detroit rapidly urbanized in the early twentieth century.

My research on Henry Ford's music and dance campaign draws on materials from the Ford Music Department archived at the Benson Ford Research Center and the Oral History Program at the Dearborn Historical Museum, both in Dearborn, Michigan. I piece together the daily activities of the dance education program from company memos, letters, newsletters, notes, and oral history interview transcripts. Materials relating to music and dance appear in both the Fairlane Papers, a collection of material from Henry and Clara Ford's Fair Lane estate, and the Ford Motor Company Archives. This overlap in the collections shows how Henry Ford's business and personal interests were often closely intertwined. Detailed newspaper articles during the period 1924-28 as well as letters to Ford provide a sense of public interest in his dance-related activities. The different editions of Ford's dance manual, "Good Morning," and the serialized version of the manual published as "A Dance a Week" column in the Dearborn Independent show what dances and music fit Ford's concept of old-fashioned dancing. These materials were produced at a moment when industrialization and innovation and tradition and rural living seemed to be diametrically opposed in American culture, and Ford positioned himself at the intersection of these forces.

\section{Old-Fashioned Dancing in a Modern Metropolis}

The Ford Motor Company Music Department took shape following a period of rapid industrialization and urbanization in southeast Michigan. Ford grew up near Detroit and left his family farm for the city as at age eighteen in $1879 .{ }^{14}$ However, the city of his youth bore little resemblance to the urban center it became. Around the time of Henry Ford's birth in 1863, Detroit was a relatively small city whose citizens were primarily of British, Scottish-Irish, or German descent. During the

\footnotetext{
${ }^{13}$ For discussion of music, dance, immigration, and Americanization in New York City, see Kathy Peiss, Cheap Amusements: Working Women and Leisure in Turn-of-the-Century New York (Philadelphia: Temple University Press, 1986); Linda Tomko, Dancing Class: Gender, Ethnicity, and Social Divides in American Dance, 1890-1920 (Bloomington: Indiana University Press, 1999). Derek Vaillant considers similar issues in Chicago during the Progressive Era in Sounds of Reform: Progressivism \& Music in Chicago, 1873-1935 (Chapel Hill: University of North Carolina Press, 2003).

${ }^{14}$ Gifford, "Henry Ford's Dance Revival," 308.
} 
nineteenth century, the city became an important Midwest manufacturing center and transportation hub because of its geographical proximity to Great Lakes shipping and the railways. The explosive growth of the auto industry created an unprecedented demand for labor. Factories relied on new immigrants and rural migrants to fill newly created positions. Between 1900 and 1920, the city's population more than tripled from 285,704 to 993,678 inhabitants. ${ }^{15}$ By 1920 , first and second generation Americans ("of foreign stock") made up 85 percent of the population, and approximately 29 percent of the population had been born overseas. ${ }^{16}$ Thus, in a single generation, the ethnicity of Detroit shifted, making the white, native-born population, to which Ford belonged, a minority.

This rapid population growth reshaped the cityscape of Detroit into a patchwork of neighborhoods divided by class status, ethnicity, language, nationality, and religion. Workers and their families adapted to life in a new environment and pursued their own traditions as best they could. Women and men socialized in dance halls, social clubs, taverns, theaters, and other venues outside the confines of the factory or the close quarters of the boarding houses and tenement houses where they lived. ${ }^{17}$ After finishing shifts, factory workers sought a place to relax and socialize with their peers, and their entertainment often included music and dancing. Venues sprang up to cater to different ethnic groups, languages, and musical tastes. ${ }^{18}$ Just as workers learned the ropes of the industrial culture of the factory from their coworkers, they learned a broader set of social behaviors and tastes from their peers in these shared urban spaces. ${ }^{19}$

Detroit's entertainment scene expanded later than that of New York or Chicago, corresponding to the city's comparatively late urbanization, but when it did, jazz music and dance generated much of the excitement. ${ }^{20}$ Several ballrooms and dance halls featured the popular music of the day-first ragtime dances, and then syncopated jazz and early swing. The first of these venues opened in the $1910 \mathrm{~s}^{21}$ In response to Prohibition, smugglers fueled Detroit's nightlife with contraband liquor ferried across the river from Windsor, Ontario, and speakeasies appeared in neighborhoods throughout the city, among them serving everyone from factory laborers

\footnotetext{
${ }^{15}$ Southeastern Michigan Council of Regional Governments, "Detroit Population History 19002000" (2002), http://www.somacon.com/p469.php.

${ }^{16}$ Joyce Shaw Peterson, American Automobile Workers 1900-1933 (Albany: State University of New York Press, 1987), 18.

${ }^{17}$ Clarence Hooker, Life in the Shadows of the Crystal Palace, 1910-1927: Ford Workers in the Model T Era (Bowling Green, OH: Bowling Green State University Popular Press, 1997), 86-96.

${ }^{18}$ Laurie A. Gomulka Palazzolo, Horn Man: the Polish-American Musician in Twentieth Century Detroit (Detroit, MI: Polish-American Music Society, 2003), 45; Thaddeus C. Radzilowski, introduction to Horn Man by Palazzolo, 3. For example, Dom Polskis were part of a constellation of public institutions that served the city's Polish communities. For a brief history of Detroit's African American entertainment district, Paradise Valley, see "Detroit's Black Bottom and Paradise Valley," Story of the Week, MotorCities, 28 January 2008, http://www.motorcities.org/Story/ Detroits+Black+Bottom+and+Paradise+Valley-37.html.

${ }^{19}$ See Meyer, “Adapting the Immigrant to the Line," 79; Peiss, Cheap Amusements, 45-51; Peterson, American Automobile Workers, xii.

${ }^{20}$ Lars Bjorn, Before Motown: A History of Jazz in Detroit, 1920-60, with Jim Gallert (Ann Arbor: University of Michigan Press, 2001), 3-10.

${ }^{21}$ Ibid., 7.
} 
to the wealthiest citizens in exclusive clubs. ${ }^{22}$ Likewise, venues featuring live music ranged from neighborhood taverns to luxurious ballrooms in downtown hotels. Although Detroit was largely segregated at this time, radio, recordings, and some clubs gave many new immigrants access to American culture via African American popular music. For example, Polish American boys heard African American jazz bands play at local venues and on commercial recordings and radio. ${ }^{23}$ Black-andtan nightclubs offered entertainment by African American dancers and musicians for mixed race audiences. ${ }^{24}$ A reviewer writing in 1925 for the primarily white readership of Detroit Saturday Night described the Palms, Detroit's first black-andtan nightclub, as a place where "the girls dance, the boys dance, whites and blacks and all shades between, mingle in a welter of syncopation." 25

Anglo-American music and dances of earlier generations were among the many traditions considered threatened by the social changes sweeping through Detroit. The influx of unskilled European and African American workers posed a problem for middle-class and elite Anglo Americans who believed that the United States' cultural and political institutions would be overwhelmed by immigrants and other newcomers. ${ }^{26}$ The Dearborn Independent took up this cause a few years before the Fords' old-fashioned dance campaign began. In an article, "Perpetuating Ideals of Idiocy and Depravity: Newspaper 'Comics' and 'Jazz' in 'Popular' Songs and Dances Assault Mental, Moral and Physical Vigor of Anglo-Saxon Race," Harvey Rexford claimed that widespread popular music "degraded Anglo-Saxon youth." He complained, "We can hardly overestimate the power of music to influence action, destructive or constructive." 27 Rexford was specifically concerned with the blues and Tin Pan Alley songs (in particular "They Call It Dancing” by Irving Berlin). ${ }^{28}$ He concluded, "Music is the soul of the dance and the jazz music with its chaotic, jerky, distorted, discordant, jarring combination of inexplicable, spasmodic sounds, reveals to the spectators, without the participants being aware of their intoxication, the primitive emotion of the jungle." 29 For Rexford, jazz music was comparable to alcohol-another "vice" that Ford opposed- an intoxicating substance that potentially caused bodily and moral harm to those who consumed it. Rexford's insistence that music and dance have great power over the individual foreshadows the dance education campaign's central message that appropriate forms of music and dance have equally uplifting potential for body and soul. Additional articles, published first in the Dearborn Independent and then republished in the pamphlet The International Jew, accused Jews of supporting African American music

${ }^{22}$ Ibid., 73.

${ }^{23}$ Palazzolo, Horn Man, 115-16.

${ }^{24}$ Bjorn, Before Motown, 20.

${ }^{25}$ Quoted in ibid., 20.

${ }^{26}$ Roger Daniels, "The Immigrant Experience in the Gilded Age," in The Gilded Age: Perspectives on the Origins of Modern America, ed. Charles W. Calhoun, 2nd ed. (New York: Rowman \& Littlefield, 2007), 92.

${ }^{27}$ Harvey Rexford, "Perpetuating Ideals of Idiocy and Depravity: Newspaper 'Comics' and 'Jazz' in 'Popular' Songs and Dances Assault Mental, Moral and Physical Vigor of Anglo-Saxon Race," Dearborn Independent, 14 January 1922, 10.

${ }^{28}$ Ibid., 11.

${ }^{29}$ Ibid.,11. 
and perverting "Anglo-Saxon" Americans' understanding of American song by controlling the commercial music industry. ${ }^{30}$ Although Ford later swore that he had no knowledge of the anti-Semitic content in the Dearborn Independent or the International Jew, these articles articulate what was then a commonly held belief that decadent non-Anglo-Saxon music led to a degradation of social mores. ${ }^{31}$ Thus, for Ford, the likely participation of his peers - management, engineers, and other white collar workers - in Detroit's popular entertainment scene signaled the end of American civilization as he knew it.

\section{Leisure Reform}

Leisure reform programs took hold in the late nineteenth century with an aim to alleviate the effects of modernization and enact social reforms that would "better" workers and promote a docile and productive workforce. The goal of uplifting workers extended to their private lives in a variety of forms. Many of the programs focused on popular working class leisure activities, particularly saloons and dance halls. In the introduction to the second edition of Substitutes for the Saloon by Raymond Calkins, Francis G. Peabody wrote that those who wish to address the problem of liquor abuse must remember, "the saloon is to millions of hard-working and tired men the chief center of refreshment and relaxation." ${ }^{32}$ Calkins connected saloon culture to alcoholism, crime, violence, poverty, prostitution, and domestic disorder, but he proposed that for reformers to truly be successful, they must create other outlets for fellowship and relaxation for working men and women, such as social clubs, coffee houses, entertainment, and education programs designed especially for them. One such example is the complex of cultural institutions constructed by Andrew Carnegie in Pittsburgh. The concert hall, library, museum, and art institute had "an explicit social agenda: to define, create, and disseminate 'the highest culture' and thereby civilize the inhabitants of the industrial city." ${ }^{33}$ Progressive Era industrialists believed that education would help uplift workers and also militate against factors that threatened productivity in the workplace.

Dance hall reform emerged from this broader movement to reform workers' leisure time. While saloons were primarily a social outlet for working-class males, dancing was one of the most popular leisure activities among unmarried workingclass women at the turn of the century. ${ }^{34}$ Reformers targeted dance halls as a cause of immoral behavior because these venues provided a place for men and women to be together physically in unsupervised circumstances. ${ }^{35}$ Settlement houses and organizations like the Young Women's Christian Association included music and

\footnotetext{
${ }^{30}$ Warnock, "The Anti-Semitic Origins of Henry Ford's Arts Education Patronage," 82-83.

${ }^{31}$ Gifford, "Henry Ford's Dance Revival and Fiddle Contests," 313.

${ }^{32}$ Francis G. Peabody, introduction to Substitutes for the Saloon, by Raymond Calkins, 2nd ed. (New York: Houghton Mifflin, 1919), xxx.

${ }^{33}$ Francis G. Couvares, "The Triumph of Commerce: Class Culture and Mass Culture in Pittsburgh," in Working Class America: Essays on Labor, Community, and American Society, ed. Michael H. Frisch and Daniel J. Walkowitz (Chicago: University of Illinois Press, 1983), 130.

${ }^{34}$ Peiss, Cheap Amusements, 88-114.

${ }^{35}$ Vaillant, Sounds of Reform 185-86.
} 
dance in recreation initiatives for both children and workers. ${ }^{36}$ Settlement workers believed that folk dance could be used to encourage physical activity but in a regulated way that emphasized proper behavior and conformity to gender codes. ${ }^{37}$ In New York City, Elizabeth Burchenal and the Girls Branch of the Public Schools Athletic League championed folk dancing as a healthful social activity for young women at park fetes. ${ }^{38}$ Educators such as Mary Wood Hinman of Hull House promoted dance as a tool for assimilation, social interaction, fun, and relief from industrial labor. ${ }^{39}$ Dance reform even extended to the commercial sphere as dance entrepreneurs Irene and Vernon Castle popularized the "Castle Walk," a refined version of the cakewalk. ${ }^{40}$ In all of these cases, reformers, whether middle-class settlement workers or wealthy industrialists, sought to change working-class culture by substituting its cultural expressions with Anglo-American forms.

Similarly, in 1914, Henry Ford attempted to reform his workers' leisure time through the Ford Motor Company's Profit Sharing Plan, also called the Five Dollar Day. This program provides an instructive precedent for understanding his oldfashioned dancing program. In 1914, the board of the company, under Ford's leadership, agreed to increase the wage of male workers, twenty-two years and older, to five dollars for an eight-hour shift. ${ }^{41}$ In order to receive this rate of pay and retain their jobs, employees had to abide by the company mandate that a worker "must show himself sober, steady, industrious, and must satisfy the superintendent and staff that his money will not be wasted in riotous living." 42 Ford founded the Profit Sharing Plan on the premise that a poor home life detracted from workers' productivity. The company sought to eliminate cultural practices and language barriers that were incompatible with assembly line work by creating an incentive to assimilate to company standards. Many new immigrants who had labored in agriculture in Europe were unfamiliar with the structured and repetitive work demanded on the assembly line. ${ }^{43}$ In labor historian Stephen Meyer's words, "a benevolent end-the uplift of the unskilled and immigrant worker-justified a manipulative and coercive means." 44 The Profit Sharing Plan lasted until early

36 Tomko, Dancing Class, 144-47; Vaillant, Sounds of Reform, 100-13.

${ }^{37}$ Peiss, Cheap Amusements, 181; Linda Tomko, “Fete Accompli: Gender, 'Folk-Dance,' and Progressive-Era Political Ideals in New York City," in Corporealities: Dancing Knowledge, Culture, and Power, ed. Susan Leigh Foster (New York: Routledge, 1996), 161.

38 Tomko, Dancing Class, 180-211.

${ }^{39}$ Ibid., 138.

${ }^{40}$ For more information on the Castles, see Mr. and Mrs. Vernon Castle, Modern Dancing (New York: Harper and Brothers, 1914); Susan C. Cook, "Watching Our Step: Embodying Research, Telling Stories," in Audible Traces: Gender, Identity, and Music, ed. Elaine Barkin and Lydia Hamessley (Zurich: Cariofoli Verlagshaus, 1999), 178-84; Susan C. Cook, "Talking Machines and Moving Bodies: Marketing Dance Music before World War I," Dancing in the Millennium: An International Conference, Proceedings 23 (2000): 77; Lewis Erenberg, “Everybody's Doin' It: The Pre-World War I Dance Craze, the Castles, and the Modern American Girl," Feminist Studies 3, nos. 1-2 (Autumn 1975): 159-61, 166.

${ }^{41}$ Nevins, Ford: The Times, the Man, and the Company, 533-34.

${ }^{42}$ Ford Motor Company, Helpful Hints and Advice to Employees to Help Them Grasp the Opportunities which Are Presented to Them by the Ford Profit Sharing Plan (Detroit, MI: Ford Motor Co., 1915), quoted in Meyer, The Five Dollar Day, 125.

${ }^{43}$ Meyer, "Adapting the Immigrant to the Line," 68.

${ }^{44}$ Meyer, The Five Dollar Day, 150. 
1922, when Ford cut it the program to save money. At this time, the company turned to a more confrontational approach to labor relations as it fought against unionization. ${ }^{45}$

Two Ford Motor Company departments_-the Sociological Department, later renamed the Education Department, and the Ford English School-carried out the social work of the Profit Sharing Plan. ${ }^{46}$ The departments were founded in 1914 and later dismantled when the company ended the Profit Sharing Plan. ${ }^{47}$ The Sociological Department enforced the company-mandated living standards set in the Profit Sharing Plan. The company assigned an investigator from the Sociological Department to evaluate each new employee's living conditions. He interviewed the worker, visited his home, and determined the family's eligibility for profit sharing. If the family failed to meet company standards, the investigator helped them reach the goals. Sometimes, this meant helping the worker find better housing or secure a loan. More often, the investigator referred foreign-born employees to the Ford English School. Not only did it teach students to speak, read, and write, but it also provided instruction in matters of hygiene, factory routine, and citizenship. ${ }^{48}$ The Ford Times article "Making New Americans" describes how Ford English School graduates called themselves "Americans" rather than ethnic Americans because they were "taught in the Ford school that the hyphen is a minus sign." 49

The graduation ceremonies of the Ford English School quite literally staged a performance of assimilation to Anglo-American culture, foreshadowing Ford's belief that by changing appearance and comportment, one could be remade as an "American." At one such event, the stage featured a large cauldron-a melting pot-stirred by Ford executives. One hundred and fourteen graduates entered the cauldron from one side wearing clothing emblematic of their home country and exited the other side dressed in suits and waving American flags. ${ }^{50}$ The spectacle and symbolism signaled Ford's belief that assimilating immigrants to Anglo-American culture would produce better workers.

${ }^{45}$ Meyer, "Adapting the Immigrant to the Line," 79.

${ }^{46}$ Several historians discuss these programs in detail. See, for example, Baldwin, Henry Ford and the Jews, 42; Grandlin, Fordlandia, 37-42; Meyer, "Adapting the Immigrant to the Line" and The Five Dollar Day; Jonathan Schwartz, "Henry Ford's Melting Pot," in Immigrants and Migrants: The Detroit Ethnic Experience, ed. David W. Hartman (Detroit, MI: New University Thought, 1974), 252-59.

${ }^{47}$ Meyer, "Adapting the Immigrant to the Line," 78.

48 "Better Workmen and Citizens," Ford Times (February 1917), 315, in vertical file, "Ford English School," Benson Ford Research Center, the Henry Ford; Georgios Paris Loizides, "'Making Men' at Ford: Ethnicity, Race, and Americanization during the Progressive Period," Michigan Sociological Review 21 (2007): 125-28; Meyer, "Adapting the Immigrant to the Line": 74-77.

49 "The Making of New Americans," Ford Times (November 1916), 152, in vertical file, "Ford English School," Benson Ford Research Center, the Henry Ford.

${ }^{50}$ Clinton C. DeWitt, "Industrial Teachers," in United States Bureau of Education, Proceedings, Americanization Conference Held Under the Auspices of the Americanization Division (Washington, D.C.: Government Printing Office, 1919), 119; also described in "The Making of New Americans," Ford Times (November 1916), 151-52, in vertical file, "Ford English School," Benson Ford Research Center, the Henry Ford; Baldwin, Henry Ford and the Jews, 42; Beth Tompkins Bates, The Making of Black Detroit in the Age of Henry Ford (Chapel Hill: University of North Carolina Press, 2012), http://carli. eblib.com/patron/FullRecord.aspx? $\mathrm{p}=1013456,42-43$; Grandin, Fordlandia, 38-39; Meyer, "Adapting the Immigrant to the Line," 77, and The Five Dollar Day, 160-61; Schwartz, "Henry Ford's Melting Pot," 254. 
Ford "human interest" stories-produced to publicize the success of the Profit Sharing Plan-illustrate the company's efforts to shape the lives of individual employees and their families. The stories rest on a value system that prized hard work, ingenuity, thrift, and adherence to the social mores of the dominant class. In each narrative, an immigrant worker who learns to succeed in the United States with the help of the Ford Motor Company. The story of "Joe," as told by his investigator, F. W. Andrews, is typical: Joe emigrated from Russia with his wife and six children. Although Joe did not have an easy time in the United States, he had "the willingness to work hard." When Andrews met the family, he found them covered in dirt, half-clad, and living in a "filthy, foul-smelling hole." Andrews secured the family a company loan and used the money to pay their bills and purchase household goods, including "a liberal amount of soap." Andrews's story ends with a ritual-like burning of the family's old possessions at the newly acquired home:

\begin{abstract}
There upon the ashes of what had been their early possessions, this Russian peasant and his wife, with tears streaming down their faces, expressed their gratitude to Henry Ford, the FORD MOTOR COMPANY, and all those who had been instrumental in bringing about this marvelous change in their lives. ${ }^{51}$
\end{abstract}

This event transforms the family from peasant immigrants into model American Ford employees. Company literature portrayed immigrants as willing participants in the Sociological Department's program to Americanize workers, as no doubt many were, given their choice between employment at a higher wage and dismissal. The depiction of the weeping family, thanking everyone who aided their transformation, evokes the paternalistic undertones of Ford's welfare program-Ford Motor Company plays the part of a strict, yet benevolent parent to the immigrant worker.

\title{
The Ford Motor Company Music Department and the Revival of Old-Fashioned Dancing
}

Personal interest in 19th century social dances may have motivated Henry Ford to form the Ford Motor Company Music Department, but at its peak, its activities reached far beyond Ford's social circle and the factory walls. According to Ford's sister Margaret Ruddiman, the Fords renewed their enthusiasm for social dancing after attending a housewarming party that she hosted in the spring of 1923: "That evening we danced the 'Virginia Reel.' There was something about the music and the gaiety that must have caught [Henry's] fancy." ${ }^{52}$ If Ruddiman's recollections are correct, then Henry Ford was sixty years old, and Clara Ford was fifty-seven. Dancing had played a significant role in their lives, as Ford met his wife Clara Bryant at a

51 "Human Interest Story, Number 9," quoted in Meyer, "Adapting the Immigrant to the Line," 72, and The Five Dollar Day, 154.

${ }^{52}$ Mrs. Stanley S. Ruddiman, The Reminiscences of Mrs. Stanley S. Ruddiman (March 1952), Reminiscence Manuscript subseries, 1951-61, Oral History subgroup, accession 65, Owen W. Bombard interview series, Benson Ford Research Center, the Henry Ford, 2. 
dance at a local Dearborn inn. ${ }^{53}$ However, the impetus for Ford's renewed fondness for the music of his youth can be understood not only as nostalgia, but also as a reaction to the immense social changes that transformed southeast Michigan during the first decades of the twentieth century.

Ford initially tried to create a community of dancers by recruiting his friends and teaching his employees. He organized informal practice sessions during the workday for company executives and engineers on company grounds. Ford's assistant secretary, Henry Cordell, remembered, "When Henry first got the idea of old-fashioned dancing, he was all pepped up over it ... [He] had a book of old-fashioned dances and had diagrams drawn on the floor of the Engineering Building in the form of footprints, showing the placement of the feet in the execution of the dances being practiced at the moment ... Frank Campsall, Waddell [Ford executives], Henry and myself would get down there, and the four of us would go through these steps with the aid of these things printed on the floor." ${ }^{44}$ Ford's employees may not have enjoyed this workplace recreation as much as their boss. Charles Sorenson, later a director and vice president of Ford Motor Company, disliked participating in the dances and actively evaded Ford's invitations. ${ }^{55}$ As a powerful chief executive and owner, Ford could compel even his top-level executives to do-si-do with each other at his whim.

According to Paul Gifford's detailed account of Henry Ford's forays into the dances of his youth, Henry and Clara Ford initially invited only those from their social milieu. ${ }^{56}$ In 1924, they hosted a Halloween dance in the barn of Ford's childhood home in Dearborn for friends and company senior executives, engineers, and their wives. ${ }^{57}$ Ford hired Benjamin Lovett, a dance instructor from Worcester, Massachusetts, to call the dance. They had met through mutual friends after the Fords acquired the Wayside Inn in Sudbury, Massachusetts in $1923 .{ }^{58}$ Lovett was an experienced professional, and he and his wife Charlotte had taught not only the nineteenth-century social dances such as quadrilles and contra dances that the Fords favored, but also modern ballroom and children's exhibition dances. ${ }^{59}$ Ford also hired an orchestra for the occasion, but there is no clear record of the instrumentation or the number of players. ${ }^{60}$ The Fords soon began hosting regular dances at the Ford Engineering Laboratory, and the Lovetts moved to Dearborn to call for dances and teach lessons. Richard Moore, the son of a Ford executive and a

\footnotetext{
${ }^{53}$ Allan Nevins, Ford: The Times, The Man, The Company, with the assistance of Frank Ernest Hill (New York: Scribner, 1954), 104.

${ }^{54}$ Harry Cordell, Reminiscences of Harry M. Cordell, Reminiscence Manuscript subseries, 195161, Oral history subgroup, accession 65. Owen W. Bombard interview series, Benson Ford Research Center, the Henry Ford (November 1952), 73.

${ }^{55}$ Allan Nevins, Ford: Expansion and Challenge, 1915-1933, with the collaboration of Frank Ernest Hill (New York: Charles Scribner's Sons, 1954), 492; Twork, Henry Ford, 62-63.

${ }^{56}$ Gifford, "Henry Ford's Dance Revival," 314.

${ }^{57}$ Gifford, "Henry Ford's Dance Revival," 316; Moreland, Green Fields and Fairer Lanes, 23; Twork, Henry Ford, 56; "Dance Parties, Guest Lists; 1910-1940, and undated," folder 12, box 134, accession 1, Fairlane Papers, Benson Ford Research Center, the Henry Ford.

${ }^{58}$ Ibid., 315; Twork, Henry Ford, 54.

${ }^{59}$ Gifford, "Henry Ford's Dance Revival," 315.

${ }^{60}$ Ibid., 316; Twork, Henry Ford, 57.
} 
student of Benjamin Lovett's at the private Greenfield Village Schools, remembered attending the Fords' dances because "you attended when you got an invitation."61

Gifford documents how Ford searched for musicians familiar with the AngloAmerican dance tunes that had been popular in southeastern Michigan during his young adulthood. Even before the Fords began hosting regular dances, Henry Ford had sought out knowledgeable fiddlers such as Jasper "Jep" Bisbee from Paris, Michigan. ${ }^{62}$ Gifford tracks the constellation of musicians who played for the dances and finds that although the instrumentation drew on late nineteenth century traditions in southeastern Michigan, Ford did not hew strictly to convention when it came to selecting the instrumentation for dance accompaniment. Musicians hired to perform were both professionals and local amateurs. A few of them, such as sousaphone/bass tuba player Maurice Castel and cimbalom player Edmund Berky, were first employed at Ford's factories before being "discovered" as musicians. ${ }^{63}$

Instruments like the sousaphone and cimbalom affirm that Ford's orchestra made no attempt to recreate the past. Gifford notes that had Ford's "priorities been nativist, he would have rejected the cymbalom." 64 Hungarian instrument manufacturer Josef V. Schunda had invented the concert cimbalom in 1873 as a fully chromatic alternative to hammered dulcimers found in central European folk traditions. However, Ford described the cimbalom in an interview with New York Times Magazine reporter Rose Feld as "an old instrument, played with little padded hammers, in much the same way as the biblical dulcimer. ... It's old and mellow and fine." 65 Ford's insistence that the cimbalom had biblical origins legitimated its place in the ensemble. However, Ford collected instruments, and this particular instrument likely appealed to him for its innovative qualities as much as it did for its supposed ancient origins and unusual sound.

The decision to hire an orchestra with fixed personnel in December 1924, soon named the Early American Orchestra, marks the moment when the Fords' dance activities crossed over from personal hobby to official company business and from their own social circle to a wider public. At this point, Ford put the Lovetts and the orchestra musicians on the company payroll and established the Music Department. Given the care and planning he put into developing Ford Motor Company, the department's official status indicates that he believed that music would be a company benefit.

Once Ford established the department, its transition from casual entertainment to systematic education happened very quickly. According to Ford's biographer William C. Richards, nine months after the Halloween dance Ford walked into Lovett's office at the company and asked him, "Have you ever heard the expression, 'Courtesy makes good friends; good manners keeps them'?" Ford proposed that

${ }^{61}$ Richard O. Moore, transcript of interview with Mr. and Mrs. Richard Moore, conducted by Donald V. Baut, Oral History Program, Dearborn Historical Museum (29 September 1976), 13.

${ }^{62}$ Gifford, "Henry Ford's Dance Revival," 313-14.

${ }^{63}$ Feld, "Ford Revives the Old-Time Dances," 2; Gifford, "Henry Ford's Dance Revival," 314$15 \mathrm{n} 40,316$.

${ }^{64}$ Gifford, "Henry Ford's Dance Revival," 316.

${ }^{65}$ Feld, "Ford Revives the Old Dances," 2. 
Lovett begin teaching Dearborn school children. ${ }^{66}$ Old-fashioned dancing, with an emphasis on deportment and style, applied a hands-on approach to learning courtesy. Ford explained the dance program was "not so much about teaching children how to dance, but teaching children courtesy and conduct that go along with the dance." 67

The dance education program reached an audience across the social spectrum rather than just local elites and colleagues of Henry Ford. Lovett began instructing dance classes for children at the Ford Engineering building in May $1925 .{ }^{68}$ The program soon moved to the Dearborn Public Schools, and after less than a year, Lovett declared the program a success and expanded it to the Detroit public schools. ${ }^{69}$ He estimated in 1928 that he taught 420 students in the two public systems. Undated lists of weekly activities that Lovett prepared for Ford show that he crisscrossed the Detroit area to teach classes at public schools in Dearborn, Detroit, Fordson, and Ypsilanti, in addition to leading classes at Ford plants and performing at company social functions. ${ }^{70}$ Classes for physical education teachers were also a major part of the program..$^{71}$ Lovett claimed that by 1940 instructors trained in his program taught "Early American dancing and deportment" to as many as one million students. ${ }^{72}$

The Music Department's activity peaked in the late 1920s as Ford sought a national audience through publications. In 1925, Ford and Benjamin and Charlotte Lovett produced the first edition of the dance manual, "Good Morning": After a Sleep of Twenty-five Years, Old-Fashioned Dancing is Being Revived by Mr. and Mrs. Henry Ford, as a tool for the revival of old-fashioned dancing. A revised version of "Good Morning" was published and more widely distributed in 1926. The first two editions are attributed to Mr. and Mrs. Henry Ford, although the Lovetts compiled the dances, and Dearborn Independent editor William J. Cameron was the likely ghostwriter for the text. ${ }^{73}$ These editions begin with essays on etiquette and technique. ${ }^{74}$ Subsequent editions from 1941 and 1943 are credited to Benjamin Lovett and provide expanded musical accompaniment, but no longer include prefatory essays. ${ }^{75}$ Many dances included in "Good Morning” were also serialized for a national readership in The Dearborn Independent's weekly column "A Dance a Week." In early 1926, the Ford Music Department orchestra recorded several sides of 78-rpm records as Henry Ford's Old-Time Dance Orchestra for Victor and Edison and as

${ }^{66}$ William C. Richards, The Last Billionaire (New York: Charles Scribner's Sons, 1948), 107.

${ }^{67}$ Ibid., 107.

${ }^{68}$ Benjamin B. Lovett, "Some Reminiscences by Benj. B. Lovett," box 134, accession 1, Fairlane Papers, Benson Ford Research Center (13 February 1940), 6.

${ }^{69}$ Ibid., 6.

${ }^{70}$ Benjamin B. Lovett, "Activities of the Week," for the weeks of 13-19 February through 20-26 March, box 134, accession 1, Fairlane Papers, Benson Ford Research Center, the Henry Ford.

${ }^{71}$ Twork, Henry Ford, 87.

${ }^{72}$ Lovett, "Some Reminiscences," 8.

${ }^{73}$ La Chapelle, "'Dances Partake of the Racial Characteristics of the People Who Dance Them," $50-51$.

${ }^{74}$ Ford, "Good Morning."

${ }^{75}$ Benjamin B. Lovett, "Good Morning": Music, Calls, and Directions for Old-Fashioned Dancing as Revived by Mr. and Mrs. Henry Ford, 3rd and 4th eds. (Dearborn, MI: Dearborn Publishing Company, 1941, 1943). 
Henry Ford's Old-Fashioned Dance Orchestra on Columbia. The group favored dance tunes such as the "Virginia Reel," "Badger Gavotte," and "Heel and Toe Polka."76 Paul Gifford provides a complete discography of recordings by Henry Ford's Orchestra, also called the Early American Orchestra, in the appendix to his essay in this journal. ${ }^{77}$ The reach of the dance program was also extended through Ford dealerships. The Dearborn Independent was distributed to dealerships around the nation. The Advertising Department instructed dealers to host dances in their showrooms in conjunction with a radio broadcast of the Early American Orchestra from New York in January $1926 .^{78}$

The national distribution of "Good Morning" and the recordings shows Henry Ford's ambitions for a revival of old-fashioned dancing and early American music. Gifford hypothesizes that Ford's dance campaign may have been modeled on his anti-Semitic campaign of 1920-21 in that "Good Morning" was serialized in the Dearborn Independent as was the International Jew. ${ }^{79}$ Although the Dearborn Independent likely reached a wider readership than the manual would have alone, the rhetoric of moral uplift coupled with dance instruction for school children, dance educators, and physical education specialists suggests a closer connection to leisure reform movements that predated Ford's dance education campaign than to the anti-Semitic campaign. The models for the dance education program were likely earlier leisure reform campaigns championed by industrialists and urban social reformers as well as the Ford Motor Company's Five Dollar Day program.

A decade later, the activities of the Ford Music Department echoed the reformoriented goals of the Sociological Department and the Ford English School. The dance manual "Good Morning" reveals the philosophy of reform underlying Ford's old-fashioned dance campaign. The opening chapter, "Return of the Dance," dismisses "ultra modern dance" for "its 'one-on-one' quality," and argues that crowded dance floors in urban cabarets exacerbated the shortcomings of popular dances: "The result is that in the modern method the movement of the dance is mostly above the feet." 80 Crowded public spaces contributed to immoral behavior, as couples had no choice but to dance in close contact with each other. The movement "mostly above the feet" refers to the explicit sexual connotations of the popular couple dances of the day. In ragtime dancing, for example, the couple slouched low and held tightly as they moved to syncopated music. "Good Morning" advocates strict bodily control for couple dances. Benjamin Lovett's instructions for the waltz position dictate physical distance between the man and woman. According to Lovett, the man's hold on his dancing partner's waist is "precisely that in which he holds a pencil, so that only the thumb and forefinger lie against the lady's dress." 81 Lovett does not leave a single movement to chance-the challenge of this position

76 "Preliminary Discography-Henry Ford's Old Time (or Old Fashioned) Dance Orchestra," accession 1195 (small), Ford Motor Company Records, Benson Ford Research Center, the Henry Ford.

${ }^{77}$ Gifford, “Henry Ford's Dance Revival,” 333-34.

78 Ibid., 326.

${ }^{79}$ Ibid., 324.

${ }^{80}$ Ford, "Good Morning," 8.

${ }^{81}$ Ibid., 15. 

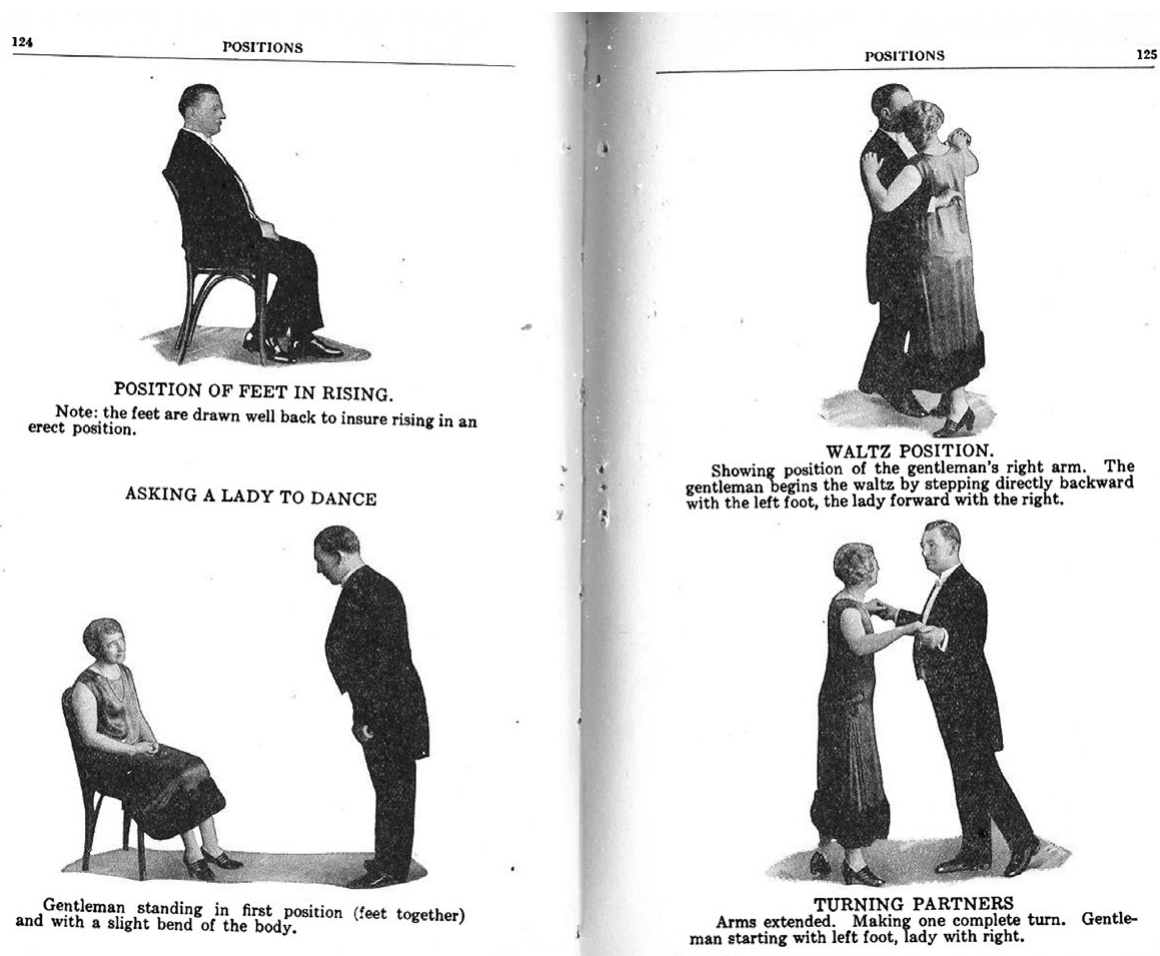

Figure 1. Ideal positions for dancing the waltz, demonstrated by Benjamin and Charlotte Lovett in the dance manual "Good Morning!" (Dearborn, MI: Dearborn Publishing, 1926), 124-25.

is exactness rather than interpretation. Each dancer has a tightly controlled posture, leaving very little room for extraneous movement, let alone intimacy (Figure 1). Lovett's method of dancing enforces a strict moral code that relies on Victorian expectations for the interaction between men and women. This rigid formality distanced dancing partners from each other and Ford's old-fashioned dancing from so-called "modern" dances. Moreover, the criticism of crowded public spaces would have resonated with local individuals and organizations concerned with the crowded living conditions in the neighborhoods surrounding Ford's factories in Dearborn and Detroit.

The musical accompaniment provided in "Good Morning" and in weekly dance columns in the Dearborn Independent also emphasized restraint and reinforced the social codes regulating dancers. The Anglo-American fiddle tunes used to accompany contra dances, quadrilles, and couple dances such as the waltz and schottische stand in stark contrast to the popular jazz and Tin Pan Alley songs that one would have heard in the dance halls of Detroit. The rhythm is tightly controlled, as opposed to the perceived freedom of "ragging." For example, the notation for piano accompaniment to "Money Musk," an English country dance in duple time, prescribes even sixteenth notes played over even eighth note subdivisions in the bass line 
(Figure 2). ${ }^{82}$ On a 1926 recording of "Money Musk," the Early American Orchestra plays in strict time and does not swing at all. ${ }^{83}$ Although other musicians, both then and now, may play similar tunes with a greater swing feel, these recordings show a very restrained interpretation of the rhythm. Lovett may have believed that strict rhythms made the recordings more practical for accompanying dance instruction, especially in settings without an experienced caller, like physical education classes. However, these recordings stand out in contrast to contemporary popular dance music of the same era. If popular music fans and dance reformers associated syncopation with urban African American culture (exemplified by Rexford's "chaotic, jerky, distorted, discordant, jarring combination of spasmodic sounds" evoking "the primitive emotion of the jungle"), then in this context, perhaps the lack of syncopation in the Early American Orchestra's accompaniment could be heard as indexical of whiteness and Victorian Anglo-American culture. ${ }^{84}$

The similarities between the Ford Music Department's goals and the company's earlier social reform programs support the notion that dance education was an effort to reform leisure activities and shape American culture. Given Ford's interest in assimilating immigrant workers, it is significant that Lovett first expanded the dance education program from Ford Motor Company to Dearborn and Detroit schools. The likelihood that students were the children of plant workers is bolstered by the company's requirement that the children of employees attend school. ${ }^{85}$ In Helpful Hints and Advice for Employees, the company advised parents to select appropriate leisure activities with the reminder: "If children's minds and energies are directed in good wholesome channels it will become a habit with them." 86 It was not unusual for industrialists to include workers' children in their welfare programs with the aim of generating respect for employers and shaping children into model workers. ${ }^{87}$

Descriptions of the dance programs reveal narratives of redemption and transformation through Ford Motor Company interventions as did the English School and the Sociological Department. In a typical story, one of several told by Lovett in his "Reminiscences," a child enters the gym for a Ford-sponsored dance class at a public school, and the principal informs Lovett that the child cannot be taught. Lovett described the pupil "as a large, dark complexioned boy with rather long hair and unkempt clothes." The teacher informed Lovett, "He is no student. He is always bullying the younger pupils and his home life is abominable, the girls just won't dance with him." ${ }^{88}$ During the first lesson, Lovett discovered that "the

${ }^{82}$ Ibid., 107.

${ }^{83}$ Early American Dances as Revived by Mr. and Mrs. Henry Ford by Ford Orchestra, compact disc copy of $78 \mathrm{rpm}$ records "recorded at Ford Engineering Laboratory, Dearborn, MI," box 2, accession 668, Ford Motor Company Records, Benson Ford Research Center, the Henry Ford (n.d.); "Preliminary Discography-Henry Ford's Old Time (or Old Fashioned) Dance Orchestra," accession 1195 (small), Ford Motor Company Records, Benson Ford Research Center, the Henry Ford.

${ }^{84}$ Rexford, Dearborn Independent, 14 January 1922, 11.

85 "Helpful Hints and Advice to Ford Employees" (Ford Motor Company, 1915), Ford Motor Company Non-Serial Publications Collection, Benson Ford Research Center, the Henry Ford, 15.

${ }^{86}$ Ibid., 15.

${ }^{87}$ Tone, The Business of Benevolence, 93.

${ }^{88}$ Lovett, "Some Reminiscences," 9. 

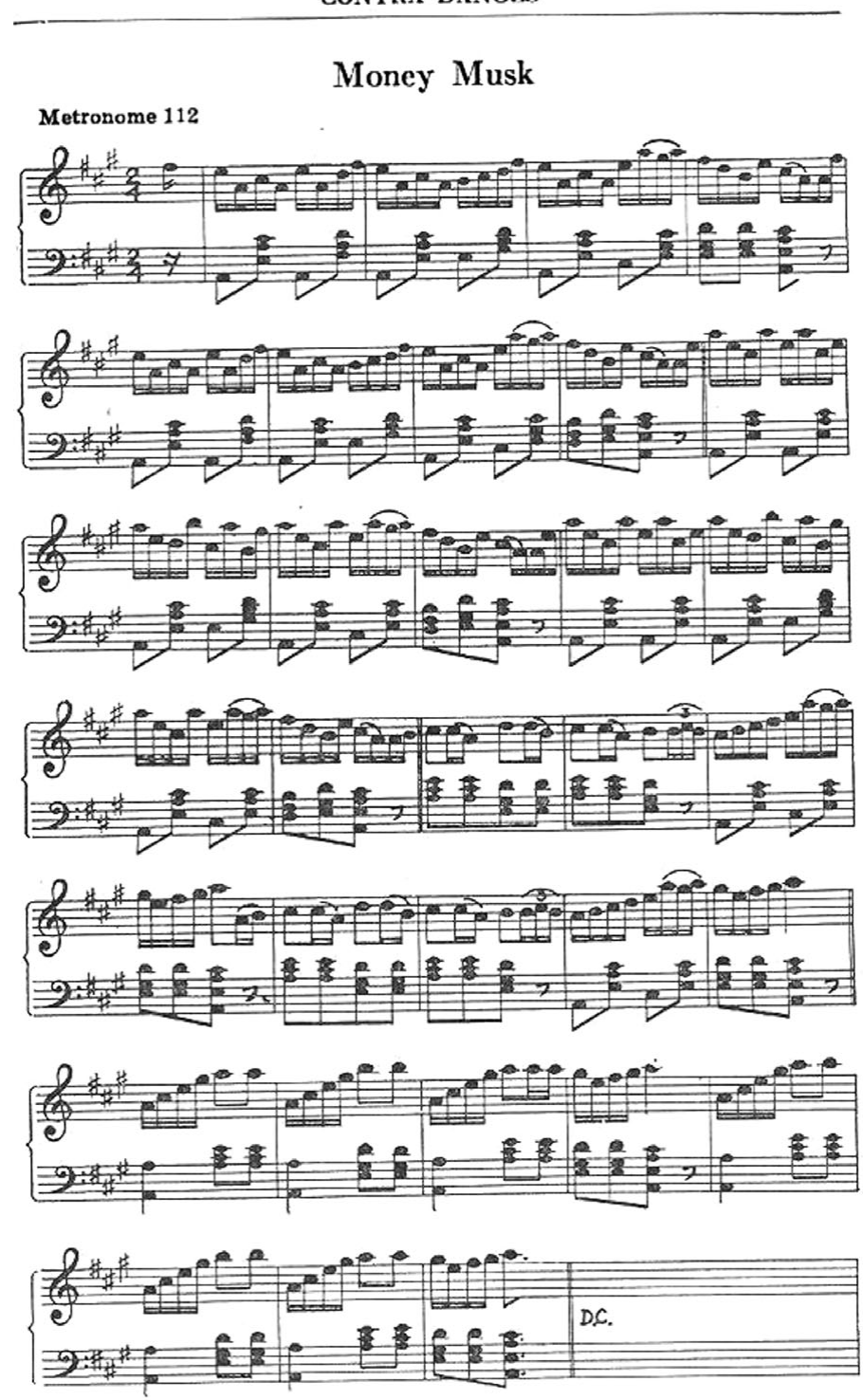

The tune of "Money Musk" took its name from the village of Moneymusk on the river Don in Aberdeenshire. It is about a century old.

Figure 2. Notation for piano accompaniment to Money Musk in the dance manual "Good Morning!" (Dearborn, MI: Dearborn Publishing, 1926), 107.

boy has a talent for time and excellent rhythm" (Lovett's underlining). ${ }^{89}$ This moment was a turning point in the boy's life. The following week, he arrived at the lesson with a haircut and polished shoes. After another week, the boy wore "a new suit of clothes, took full charge of set formation, and assisted in securing partners for others. ${ }^{\prime 90}$ Once dancing lessons transformed his personality and physical

${ }^{89}$ Ibid., 10.
${ }^{90}$ Ibid., 10. 
appearance, he went on to compete successfully in dance contests. After graduation, the boy found employment at a downtown hotel, an achievement Lovett attributed to the skills he learned in the dance classes. Lovett's narrative contains the same basic features as the Ford "human interest" story describing Joe, the Russian immigrant. The racialized language used to describe the boy's physical appearance point to non-Anglo descent, and his anti-social behavior mark him as an outsider to school life. By learning to dance, he learns to conform to the social standards of the dominant Anglo-American culture. As with Andrews, the Sociological Department investigator, Lovett's intervention enables the boy to become a productive community member. Dance lessons succeeded where school authorities were unable, reinforcing the power of old-fashioned dancing and the Ford Motor Company.

The features of the social dances championed by the Ford Music Department suggest that they may have served as an object lesson in the virtues of modern factory work. The dances bore a strong resemblance to Ford's moving assembly line. First, group dances like contra dances are activities in which individuals or pairs of dancers execute interlocking patterns of movement that propel couples down the line towards one end of the hall. Second, group dances require the individual to execute precise, efficient movements in exact time. If a dancer loses a step or miscounts, the dancers can lose their places in the line. The Early American Orchestra drove the rhythm and tempo of the dances with the same efficiency as the motors propelling the assembly line. Finally, the dancers must defer to the authority of the caller. If the dancers fail to respond properly to his instructions, the line breaks down.

As with the Five Dollar Day, existing accounts primarily reflect the perspectives of Ford and those who worked to bring his goals to fruition. One is left to wonder, however, whether or not the children who participated in dance classes viewed their activities in the same light. Perhaps, for them, it was an opportunity to burn off energy outside the classroom, learn something new, and socialize with their peers; learning deportment and physical discipline may have been incidental to any fun they had during dance classes.

Public reaction to Ford's program confirmed that anxiety over sexuality shaped by fear of social changes brought on by industrialization and rapid urbanization were manifested through dance. Ford claimed that he did not set out to reform socalled "modern" dances, but his own views on the value of dance in teaching proper comportment, editorials such as the one quoted at the beginning of this essay, and the response of individuals to Ford's public statements suggest that Ford found an audience enthusiastic for dance reform. ${ }^{91}$ After the publication of Rose Feld's 1925 article, "Ford Revives the Old-time Dances," in the New York Times Magazine, individuals from around the country wrote personal letters to Ford offering their observations and support for his activities. Many refer to their age as similar to Ford's, suggesting that his revival resonated most with older individuals who had firsthand experience with the dances he championed. Several also offered their

${ }^{91}$ Feld, "Ford Revives the Old Dances," 1. 
own critiques of popular culture. One correspondent, "VWA" from Titusville, New Jersey, wrote:

This article was published at an opportune time; for, the fox-trot and other undignified dances are bad for the youth of the Nation. Personally, I think, they are largely responsible for bobbed haired women and their short and transparent gowns. I have seen them on the street wearing but little more than a smile. ... Mr. Ford, no doubt, conceived the idea of counteracting this by reviving the things of a higher and better order. ${ }^{92}$

The writer associates popular dances like the foxtrot with changes in women's behavior and appearance symbolized by the stereotypical image of the flapper. In addition to disrupting normative gender ideology, these dances also carried racial connotations linked to their roots in African American popular music. Susan Cook points out that race drove much what she calls "the fears and delights of 'white' dancers stimulated by 'black' music." She argues, "through characteristic syncopation, 'white' bodies might act 'black." 93 Through dance, the body becomes the focus of gender, race, and class anxieties.

When Henry Ford, the Ford Music Department, journalists, and those sympathetic to Ford's ideas defined old-fashioned dance and early-American music in opposition to the popular or modern dances of the day, they invested the older dances with the potential to help immigrants and first-generation Americans learn whiteness. By initially targeting children who lived in the urban centers of southeast Michigan, Ford sought out a population that would have been viewed through a prism of class, ethnicity, and race as "nonwhite" or "not-quite-white." ${ }^{4}$ However, the Ford Motor Company's efforts at Americanization and leisure reform did not extend to African American workers. ${ }^{95}$ During World War I and after the passage of the Immigration Reform Act of 1924, the promise of jobs in the auto industry attracted many African Americans to Detroit from the rural South, and Ford hired more African Americans than the other automotive companies in Detroit. ${ }^{96}$ The automaker recruited African American workers through churches and relied on clergy, rather than company programs, to informally police behavior deemed incompatible with employment at Ford factories. ${ }^{97}$

Ford no doubt wanted his revival of old-fashioned music and dance to leave a lasting legacy, but by comparison to his other efforts at social reform, the dance campaign is not as well known. The Detroit Americanization Committee, a subcommittee of the Detroit Board of Commerce, used the Ford English School as a model for language training and assimilation of workers across area industries. ${ }^{98}$

\footnotetext{
${ }^{92}$ VWA to Mr. Cordell (Henry Ford's assistant), 16 August 1925, Letters to H. Ford on "OldFashioned Dancing," folder 5, box 2, accession 356, Hayward S. Ablewhite Collection, Benson Ford Research Center, the Henry Ford.

${ }^{93}$ Cook, "Talking Machines and Moving Bodies," 75.

${ }^{94}$ Karen Brodkin, How the Jews Became White Folks and What That Says about Race in America (New Brunswick, NJ: Rutgers University Press, 1998), 25-30.

${ }^{95}$ Beth Tompkins Bates, The Making of Black Detroit in the Age of Henry Ford (Chapel Hill: University of North Carolina Press, 2012), 46, 51.

96 Ibid., 17.

${ }^{97}$ Ibid., 74.

${ }^{98}$ Hooker, Life in the Shadows, 115.
} 
Other public policy efforts like the Peace Ship, Ford's non-governmental envoy to promote pacifism at the onset of World War I, did not meet with success but remain part of his legacy. To this day, Ford is remembered for efforts to reform public health such as his campaign against smoking through the publication of The Case Against the Little White Slaver. ${ }^{99}$ The Ford Music Department spurred a national dance education campaign, but the reform dimension lost relevance over time. ${ }^{100}$ Oldfashioned dancing received the most publicity in 1926, corresponding to Ford's popularity and the media attention given to the dance manual "Good Morning." Benjamin and Charlotte Lovett taught for Ford until their retirement in 1944, and the Early American Orchestra continued its activities until Ford Motor Company dissolved the Music Department following Henry Ford's death in $1947 .{ }^{101}$

Although the Music Department's activities waned over time, old-fashioned dancing was introduced in Ford-sponsored education programs in remote places such as the Brazilian Amazon and rural Georgia, where the Ford Motor Company was attempting to cultivate raw materials for use in manufacturing. During the period 1928-1945, the Ford Motor Company established not only rubber plantations in Brazil, but also a housing complex for workers modeled on North American architecture complete with schools, a movie house, and regular leisure activities such as square dances. ${ }^{102}$ Although neither the Fords nor the Lovetts visited the Amazon community, Ford attempted to apply his methods of production and social mores to the development of rubber plantations and the communities surrounding them. ${ }^{103}$

Ford made similar efforts in the rural United States. In the 1920s, Henry and Clara Ford became acquainted with Martha Berry, a wealthy educator, who had founded the Berry Schools on her plantation in Rome, Georgia in 1902. ${ }^{104}$ The Fords made annual visits to the schools and supplied them with materials from the old-fashioned dance campaign. ${ }^{105}$ After purchasing vast tracts of land for agricultural production in Bryan County, Georgia, the Fords turned their attention to the Ways Consolidated Schools. ${ }^{106}$ The Lovetts stayed for extended residencies during the early 1940s, and the Early American Orchestra traveled to Ways to accompany at least one dance hosted at the high school in April 1940. Once Henry Ford passed away and the company no longer found investment in the production of raw materials expedient, patronage of the arts and education programs ceased in these communities along with industrial operations. The inclusion of old-fashioned dancing in these various programs indicates the degree to which Ford considered social dancing central to his education mission. Emery C. Warnock suggests that in the rural South, Ford "found the children of his youth-unworldly and eager for attention," but he likely also considered them untainted by modernity and receptive to his values. ${ }^{107}$

\footnotetext{
${ }^{99}$ Henry Ford, The Case Against the Little White Slaver (Detroit, MI: Henry Ford, 1914; rev. 1916).

${ }^{100}$ Peterson, American Automobile Workers, 24.

101 Twork, Henry Ford, 217, 218, 222.

102 Grandin, Fordlandia, 8-9.

${ }^{103}$ Ibid., 186-89, 278-93.

${ }^{104}$ Warnock, “The Anti-Semitic Origins of Henry Ford's Arts Education Patronage,” 91.

105 Ibid., 92.

${ }^{106}$ Ibid., 93-5.

${ }^{107}$ Ibid., 101.
} 


\section{Conclusion}

The Music Department's approach to leisure reform, backed by the enormous resources of the Ford Motor Company, are testimony to Ford's belief that he could instill a secular value system rooted in a mythological, pre-industrial past through old-fashioned dancing. Many have noted with irony that Henry Ford believed that mechanization would relieve the burden of farm labor, only to rue the immense cultural changes made possible by the automobile and mass industrialization. ${ }^{108}$ Although Ford was famously quoted as saying, "history is bunk," he viewed the past as an important tool the present could use to improve the future. ${ }^{109}$ The rapid growth of the automobile industry contributed to a host of economic, social, and cultural changes that gave rise to new modes of consumption, entertainment, and sociability. Although Ford did not comment on whether or not he believed that mass manufacturing or the automobile contributed to changes in leisure activities, he did believe that the "correct" dances could be used to counteract the sexuality and liberalized social relations on display in ragtime and jazz. At the same time, these dances could be used to develop students' physical and social skills in ways suitable for the twentieth-century labor force. In Ford's view, through learning social dances of the past, one could glean important lessons for living in the present.

The musical legacy of the Ford Music Department opens the door to further questions about the cultural politics of leisure reform. The notion that music and dance could transform a "dark complexioned" boy into a model student points to the racial politics of Americanization during the early twentieth century. Programs to assimilate workers through leisure activities focused primarily on recent immigrants to the United States and rarely, if ever, acknowledge the presence of African Americans. New migrants from the South faced many of the same difficulties adapting to the demands of factory life as their European counterparts, and their leisure activities also included saloons and commercial dance halls. Moreover, white middle-class and elite reformers often objected most to the aspects of mainstream American popular music that derived from African American music culture. Based on my preliminary observations, it seems that the absence of African Americans from reformers' dialogues on leisure reform suggests that racial politics determined who could be assimilated to Anglo-American, middle-class culture.

Ford's campaign may have contributed the maintenance of nineteenth-century dances such as contra dancing. Through the dance manual and education programs, these dances spread beyond the rural communities where they had originated. I first learned of Ford's interest in dancing at a contra dance I attended in Providence, Rhode Island as a college student. I had attended contra dances with my parents in northern Maine in the late 1970s and early 1980s. I doubt Ford would have approved of the progressive social beliefs of the hippies and back-to-the-landers

${ }^{108}$ See for example, Gifford, "Henry Ford's Dance Revival and Fiddle Contests," 324; Grandin, Fordlandia, 40-42; Mirjana Laušević, Balkan Fascination (New York: Oxford University Press, 2007), 228; Warnock, “The Anti-Semitic Origins of Henry Ford's Arts Education Patronage,” 79.

${ }^{109}$ Steven Conn, Museums and American Intellectual Life, 1876-1926 (Chicago: University of Chicago Press, 1998), 152, 187. 
dancing in New England, but like Ford, many of these individuals embraced these dances because they, too, viewed them as rooted in a pastoral history of the rural United States. $^{110}$

The notion that social dancing is a tool for social uplift lives on. In creating his program, Ford built on preexisting notions that the correct social dances could improve deportment and reform the body, and his legacy continues in contemporary dance education programs. The documentary Mad Hot Ballroom, released in 2005, follows fifth graders enrolled in competitive ballroom dancing in New York City public schools. The program emphasizes the positive virtues that the kids learn through the values embodied in social dance. Although the film showcases the diversity of the students participating in the program, it still carries a strong message of corrective behavior and normative values. Ballroom dancing teaches the children to become "ladies and gentlemen."

Industrial paternalism no longer has the same influence on culture in the United States as it did in the early twentieth century. The remaining powerhouses of the American auto industry-Ford Motor Company, General Motors, and Chryslerhave emerged from yet another round of cutbacks and restructuring. Despite recent relative success in the auto industry, the economy of southeast Michigan continues to falter, and the city of Detroit declared bankruptcy in 2013. Many of the neighborhoods that figured so prominently in the entertainment industry in Detroit during the 1920s are no longer vibrant. Blocks of abandoned houses span the city, and the center of a largely African American jazz scene-Paradise Valley-was demolished to make way for highways during the late 1950s. ${ }^{112}$ How best to stabilize the city's finances, maintain infrastructure, and honor the history and culture of its residents remains an open question. However, the Ford Motor Company Music Department shows that industry was once very much entwined in leisure and private life of its employees and communities in southeastern Michigan. Henry Ford's passionate advocacy for old-fashioned dancing and the influence he hoped it would have over leisure activities in the United States reminds us of the enormous influence that he and his company once wielded. The old-fashioned dancing campaign suggests that rather than solely being an exercise in nostalgia or atonement for promoting an increasingly industrialized and commercialized world, Ford and other elite Americans were also trying to shape an American culture that could be entrepreneurial, innovative, and technologically advanced while also embracing nostalgia for a simpler, purer, and more orderly, albeit, mythological past. Ford believed that through dancing, one could adopt Anglo-American Victorian values and learn deportment, efficiency, and habits appropriate to contemporary society and labor.

110 Thomas Turino, Music as Social Life (Chicago: University of Chicago Press, 2008), 169-73. Turino suggests that for many contemporary participants, old-time music and contra dance continue to be indexical of rural Anglo-American traditions.

${ }^{111}$ Mad Hot Ballroom, DVD, directed by Marilyn Agrelo (Hollywood, CA: Paramount Pictures, 2005).

${ }^{112}$ Thomas J. Sugrue, The Origins of the Urban Crisis: Race and Inequality in Postwar Detroit (Princeton, NJ: Princeton University Press, [1996], 2005), 47-48. 


\section{References}

\section{Archival Sources}

Bentley Historical Library. University of Michigan. Ann Arbor, MI.

Dearborn Historical Museum. Dearborn, MI.

Fair Lane Papers, 1835-1950. Benson Ford Research Center. The Henry Ford. Dearborn, MI.

"Ford English School" (Vertical File). Benson Ford Research Center. The Henry Ford. Dearborn, MI.

Ford Motor Company Non-Serial Publications Collection. Benson Ford Research Center. The Henry Ford. Dearborn, MI.

Ford Motor Company Records. Benson Ford Research Center. The Henry Ford. Dearborn, MI.

Owen W. Bombard Interview Series, 1951-1961 (Accession 65). Benson Ford Research Center. The Henry Ford. Dearborn, MI.

\section{Newspapers}

Dearborn Independent

Ford Times

Literary Digest

New York Times

\section{Books and Articles}

Baldwin, Neil. Henry Ford and the Jews. New York: Public Affairs, 2001.

Bates, Beth Tompkins. Making of Black Detroit in the Age of Henry Ford. Chapel Hill: University of North Carolina Press, 2012. http://carli.eblib.com/patron/ FullRecord.aspx? $\mathrm{p}=1013456$.

Bjorn, Lars. Before Motown: A History of Jazz in Detroit, 1920-60. With Jim Gallert. Ann Arbor: University of Michigan Press, 2001.

Brodkin, Karen. How the Jews Became White Folks and What That Says About Race in America. New Brunswick, NJ: Rutgers University Press, 1998.

Calkins, Raymond. Substitutes for the Saloon. 2nd ed. New York: Houghton Mifflin, 1919.

Castle, Mr. and Mrs. Vernon. Modern Dancing. New York: Harper and Brothers, 1914.

Conn, Steven. Museums and American Intellectual Life, 1876-1926. Chicago: University of Chicago Press, 1998.

Cook, Susan C. “Talking Machines and Moving Bodies: Marketing Dance Music before World War I." Dancing in the Millennium: An International Conference, Proceedings 23 (2000): 75-78.

—. "Watching Our Step: Embodying Research, Telling Stories." In Audible Traces: Gender, Identity, and Music, edited by Elaine Barkin and Lydia Hamessley, 178-84. Zurich: Cariofoli Verlagshaus, 1999.

Couvares, Francis G. "The Triumph of Commerce: Class Culture and Mass Culture in Pittsburgh." In Working Class America: Essays on Labor, Community, and 
American Society, edited by Michael H. Frisch and Daniel J. Walkowitz, 123-52. Urbana: University of Illinois Press, 1983.

Daniels, Roger. "The Immigrant Experience in the Gilded Age.” In The Gilded Age: Perspectives on the Origins of Modern America, edited by Charles W. Calhoun, 75-99. 2nd ed. New York: Rowman \& Littlefield, 2007.

DeWitt, Clinton C. "Industrial Teachers." In Proceedings, Americanization Conference Held Under the Auspices of the Americanization Division, United States Bureau of Education, 114-19. Washington, D.C.: U.S. Government Printing Office, 1919.

Erenberg, Lewis. “Everybody's Doin' It: The Pre-World War I Dance Craze, the Castles, and the Modern American Girl." Feminist Studies 3, nos. 1-2 (Autumn 1975): 155-70.

Ford, Henry. The Case Against the Little White Slaver. Detroit, MI: Henry Ford, 1914. Rev. ed., 1916.

Ford, Mr. and Mrs. Henry. "Good Morning": After a Sleep of Twenty-Five Years OldFashioned Dancing is Being Revived by Mr. and Mrs. Henry Ford. Dearborn, MI: Dearborn Publishing Company, 1926. Subsequent editions published as Benjamin B. Lovett, "Good Morning": Music, Calls, and Directions for Old-Fashioned Dancing as Revived by Mr. and Mrs. Henry Ford. 3rd and 4th eds. Dearborn, MI: Dearborn Publishing, 1941, 1943.

Gifford, Paul M. "Henry Ford's Dance Revival and Fiddle Contests: Myth and Reality." Journal of the Society for American Music 4, no. 3 (2010): $307-$ 38.

“Jasper E. 'Jep’ Bisbee: Old-Time Michigan Dance Fiddler.” The Old Time Herald 9, no. 6 (Winter 2004-2005): http://www.oldtimeherald.org/archive/ back_issues/volume-9/9-6/jasper-bisbee.html.

Goertzen, Chris. “The Transformation of American Contest Fiddling." Journal of Musicology 6, no. 1 (Winter 1988): 107-29.

Grandin, Greg. Fordlandia. New York: Metropolitan Books, Henry Holt, 2009.

Hooker, Clarence. Life in the Shadows of the Crystal Palace, 1910-1927: Ford Workers in the Model T Era. Bowling Green, OH: Bowling Green State University Popular Press, 1997.

La Chapelle, Peter. "Dances Partake of the Racial Characteristics of the People Who Dance Them': Nordicism, Antisemitism, and Henry Ford's Old-Time Music and Dance Revival." In The Song Is Not the Same: Jews in American Life, edited by Bruce Zuckerman, Josh Kun, and Lisa Ansell, 29-70. The Jewish Role in American Life 8. West Lafayette, IN: Purdue University Press, 2011.

Laušević, Mirjana. Balkan Fascination. Oxford: Oxford University Press, 2007.

Lewis, David. The Public Image of Henry Ford. Detroit, MI: Wayne State University Press, 1976.

Loizides, Georgios Paris. “'Making Men’ at Ford: Ethnicity, Race, and Americanization during the Progressive Period.” Michigan Sociological Review 21 (Fall 2007): 109-48.

Meyer, Stephen, III. The Five Dollar Day: Labor Management and Social Control in the Ford Motor Company, 1908-1921. Albany: State University of New York Press, 1981. 
"Adapting the Immigrant to the Line: Americanization in the Ford Factory, 1914-1921." Journal of Social History 14, no. 1 (Autumn 1980): 67-82.

Moreland, Faye Witt. Green Fields and Fairer Lanes: Music in the Life of Henry Ford. Tupelo, MS: Five Star, 1969.

Nevins, Allan. Ford: The Times, The Man, The Company. Vol. 1. With the collaboration of Frank Ernest Hill. New York: Charles Scribner's Sons, 1954.

- Ford: Expansion and Challenge, 1915-1933. Vol. 2. With the collaboration of Frank Ernest Hill. New York: Charles Scribner's Sons, 1954.

Palazzolo, Laurie A. Gomulka. Horn Man: the Polish-American Musician in Twentieth Century Detroit. Detroit, MI: Polish-American Music Society, 2003.

Peabody, Francis G. Introduction to Substitutes for the Saloon, by Raymond Calkins. 2nd ed. New York: Houghton Mifflin, 1919.

Peiss, Kathy. Cheap Amusements: Working Women and Leisure in Turn-of-theCentury New York. Philadelphia: Temple University Press, 1986.

Peterson, Joyce Shaw. American Automobile Workers 1900-1933. Albany: State University of New York Press, 1987.

Quigley, Colin. "Reflections on the Hearing to 'Designate the Square Dance as the American Folk Dance of the United States': Cultural Politics and an American Vernacular Dance Form." Yearbook for Traditional Music 33 (2001): 45-57.

Radzilowski, Thaddeus C. Introduction to Horn Man: The Polish-American Musician in Twentieth Century Detroit, by Laurie A. Gomulka Palazzolo, 1-5. Detroit, MI: Polish-American Music Society, 2003.

Richards, William C. The Last Billionaire-Henry Ford. New York: Charles Scribner's Sons, 1948.

Schwartz, Jonathan. "Henry Ford's Melting Pot.” In Immigrants and Migrants: The Detroit Ethnic Experience, ed. David W. Hartman, 252-59. Detroit, MI: New University Thought, 1974.

Sugrue, Thomas J. The Origins of the Urban Crisis: Race and Inequality in Postwar Detroit. Princeton, NJ: Princeton University Press, [1996], 2005.

Tomko, Linda. Dancing Class: Gender, Ethnicity, and Social Divides in American Dance, 1890-1920. Bloomington: Indiana University Press, 1999.

_. "Fete Accompli: Gender, "Folk-Dance," and Progressive-Era Political Ideals in New York City." In Corporealities: Dancing Knowledge, Culture, and Power, edited by Susan Leigh Foster, 155-76. New York: Routledge, 1996.

Tone, Andrea. The Business of Benevolence: Industrial Paternalism in Progressive America. Ithaca, NY: Cornell University Press, 1997.

Turino, Thomas. Music as Social Life: The Politics of Participation. Chicago: University of Chicago, 2008.

Twork, Eva O’Neal. Henry Ford and Benjamin B. Lovett: The Dancing Billionaire and the Dancing Master. Detroit, MI: Harlo, 1982.

Vaillant, Derek. Sounds of Reform: Progressivism \& Music in Chicago, 1873-1935. Chapel Hill: University of North Carolina Press, 2003.

Warnock, Emery C. "The Anti-Semitic Origins of Henry Ford's Arts Education Patronage." Journal of Historical Research in Music Education 30, no. 2 (April 2009): 79-102. 


\section{Media}

Mad Hot Ballroom. DVD. Directed by Marilyn Agrelo. Hollywood, CA: Paramount Pictures, 2005.

Southeastern Michigan Council of Regional Governments. "Detroit Population History 1900-2000.” 2002. http://www.somacon.com/p469.php. 